\title{
IN VITRO ANTIFUNGAL, ANTIBACTERIAL ACTIVITIES AND NUTRITIONAL VALUE OF NINE CAMEROONIAN EDIBLE VEGETABLES AND SPICES
}

\author{
Fabrice N. B. Wandji ${ }^{1}$, Aduni U. Achidi ${ }^{1}$, Moses N. Ngemenya ${ }^{1,2 \bowtie}$, \\ Kennedy D. Nyongbela ${ }^{3}$, Bernard Tiencheu ${ }^{1}$ \\ ${ }^{1}$ Department of Biochemistry and Molecular Biology, University of Buea \\ P.O. Box 63 Buea, South West Region, Cameroon \\ ${ }^{2}$ Department of Medical Laboratory Science, University of Buea \\ P.O. Box 63 Buea, South West Region, Cameroon \\ ${ }^{3}$ Department of Chemistry, University of Buea \\ P.O. Box 63 Buea, South West Region, Cameroon
}

\begin{abstract}
Background. The high medicinal potential of plants, including edible vegetables, is well documented. Vegetables can afford significant health benefits to consumers, depending on their medicinal properties and nutritional value. This study analysed the antimicrobial activity and nutrient contents of nine commonly consumed Cameroonian vegetables and spices for which such information is at present limited.

Material and methods. The antimicrobial activity of the methanol extracts of the vegetables was evaluated by disc diffusion and microdilution methods against three tomato fungi and two pathogenic bacteria species. Results. The inhibition zones against fungi ranged from 10-21 mm; Irvingia gabonensis and Apium graveolens showed the highest zones with dose-dependent activity against Fusarium solani and F. oxysporum. The inhibition zones against bacteria ranged from 8-12 $\mathrm{mm}$ with Allium porrum having the highest inhibition zone $(12 \mathrm{~mm})$. Irvingia gabonensis seeds had the lowest minimum inhibitory concentration (MIC) of $6.25 \mathrm{mg} / \mathrm{mL}$ against $F$. solani and also had the lowest MIC of $2 \mathrm{mg} / \mathrm{mL}$ against $S$. aureus. Proximate composition and mineral analysis were carried out on the most active antimicrobial vegetables, I. gabonensis seeds and $A$. graveolens. I. gabonensis seeds were rich in lipids $(69.90 \pm 0.14 \%)$ while $A$. graveolens leaves were rich in protein $(35.35 \pm 0.49 \%)$. For macro minerals, phosphorous had the highest concentration in I. gabonensis seeds $(359.67 \pm 1.89 \mathrm{mg} / 100 \mathrm{~g})$ and A. graveolens leaves $(622.14 \pm 2.69 \mathrm{mg} / 100 \mathrm{~g})$. Iron content was the highest of micro minerals in I. gabonensis seeds $(276.51 \pm 1.41 \mathrm{mg} / 100 \mathrm{~g})$ while zinc concentration was the highest in $A$. graveolens leaves $(16.86 \pm 0.27 \mathrm{mg} / 100 \mathrm{~g})$.

Conclusion. This study has shown that three of the nine Cameroonian vegetables, I. gabonensis seeds, Apium graveolens and $A$. porrum, may potentially offer both antimicrobial and nutritional benefits to consumers. Consequently, further studies should be conducted to ascertain the effect of cooking and other factors in order to maximize these benefits.
\end{abstract}

Keywords: vegetables, spices, edible, nutritional, antimicrobial

Funding Source Declaration. Funded by University of Buea 2016 Budget. 


\section{INTRODUCTION}

The burden of infectious diseases remains high and is a major contributor to global morbidity (Roser and Ritchie, 2016). This situation necessitates the constant search for suitable antimicrobials. Plants remain a major source of drugs principally derived from their secondary metabolites, which have been used to treat a wide range of diseases (Veeresham, 2012). Vegetables are part of the natural flora and a major part of the human diet consumed worldwide, not only as a source of nutrients but also vitamins, minerals, fibre or roughage (Slavin and Lloyd, 2012). Vegetables also contain various phytochemicals, which have both protective (carotenoids, flavonoids, indoles, phenols, limonene, sterols etc.) and harmful effects (aflatoxin, nitrates, goitrogens, phenolic compounds, enzyme inhibitors etc.) in the human body (Slavin and Lloyd, 2012). There are several reports on the beneficial effects of vegetable consumption. Findings show that frequent intake of vegetables is associated with a decreased incidence and mortality of chronic diseases, and may prevent cancers, cardiovascular diseases and obesity (Oguntibeju et al., 2013). There are also several reports on the antimicrobial (antibacterial, antifungal) activity of some edible vegetables and spices.

A wide variety of vegetables and spices are cultivated in Cameroon and particularly in Buea, the study area (Ngome and Foeken, 2012). The nine vegetables and spices investigated in this study are widely consumed. In most parts of Cameroon, the fresh young shoots of Solanum nigrum are cooked as leafy vegetable sauce and served with preparations of corn fufu, plantains and some tubers (Asseng et al., 2017). In areas where Manihot esculenta leaves are eaten as a relish, it is prepared by pounding and grinding of the leaves and young shoots before cooking, and consumed as a main meal or accompaniment to various cereal, root and tuber foods (Achidi et al., 2008). Allium porrum, Apium graveolens and Petroselinum crispum are spices used routinely as flavor enhancers when cooking sauces and vegetable meals. Amaranthus cruentus and Telfairia occidentalis are usually blanched before further preparation and eaten with boiled plantains, tubers and dough made from cereal or tuber flours. Gnetum africanum and Irvingia gabonensis are a regular part of the menu in homes, restaurants and social events (Abia et al., 2007). Gnetum africanum is a tough vegetable softened with Talinum triangulare leaves when being cooked.

However, there is a lack of information on the medicinal and health benefits that may be derived from the consumption of these vegetables and spices. Antibacterial activity has been recorded for Irvingia gabonensis bean or seed, and leaves of Manihot esculenta and Solanum nigrum vegetables grown in the West region of Cameroon (Nayim et al., 2018; Noumedem et al., 2013). However, there is no or limited information on the antibacterial and or antifungal activities of Allium porrum, Amaranthus cruentus, Manihot esculenta and Petroselinum crispum grown locally.

The preservative properties of these vegetables acting against microbial damage to foods has also not been extensively investigated. For instance, the tomato, which is widely cultivated in Cameroon, is highly susceptible to fungal attack leading to a high post-harvest loss (Fontem et al., 1999). Some fungi which attack tomato fruits threaten human health by producing mycotoxins capable of inducing mycotoxicosis following ingestion or inhalation (Wagacha and Muthomi, 2008), hence there is a need for an effective preservative for these fruits. Furthermore the nutritional value of the local varieties has not been determined. This information will reveal the percentage of recommended dietary allowance (RDA) that can be gained from them and indicate the consumption of these vegetables in order to gain optimal benefits. This study focused on Cameroonian vegetables and spices commonly consumed in the study area which have not been extensively investigated for both antimicrobial activity and their nutritional value.

\section{MATERIALS AND METHODS}

\section{Collection, processing and preparation of extracts}

The vegetables and spices, were bought from Muea market in Buea, South West Region and identified by Mr. Peter Njimba, a botanist at the herbarium of the Limbe Botanical Garden, Cameroon. The edible parts used in this study are shown in Table 1. The plant parts were chopped, air-dried for 3 weeks then ground to a fine powder and weighed. Each powder was macerated by submerging in methanol for three 
Wandji, F. N. B., Achidi, A. U., Ngemenya, M. N., Nyongbela, K. D., Tiencheu, B. (2019). In vitro antifungal, antibacterial activities and nutritional value of nine Cameroonian edible vegetables and spices. Acta Sci. Pol. Technol. Aliment., 18(3), 333-341. http:// dx.doi.org/10.17306/J.AFS.2019.0664

Table 1. Information, yields and antibacterial activities of methanol extracts of vegetables and spices

\begin{tabular}{|c|c|c|c|c|c|c|}
\hline \multirow[b]{2}{*}{$\begin{array}{c}\text { Species } \\
\text { voucher number }\end{array}$} & \multirow[b]{2}{*}{ Family } & \multirow[b]{2}{*}{ Local name(s) } & \multirow[b]{2}{*}{$\begin{array}{c}\text { Edible plant part; } \\
\text { used }\end{array}$} & \multicolumn{3}{|c|}{ Extract } \\
\hline & & & & $\begin{array}{c}\text { weight } \\
\mathrm{g}\end{array}$ & $\begin{array}{c}\text { yield } \\
\%\end{array}$ & $\begin{array}{c}\text { zone of } \\
\text { inhibition* } \\
\mathrm{mm}\end{array}$ \\
\hline $\begin{array}{l}\text { Allium porrum } \\
\text { SCA } 7762\end{array}$ & Alliaceae & Leeks & $\begin{array}{l}\text { stem and leaves; } \\
\text { spice }\end{array}$ & 0.80 & 1.46 & $12 \pm 0.0$ \\
\hline $\begin{array}{l}\text { Amaranthus cruentus } \\
\text { SCA } 6350\end{array}$ & Amaranthaceae & Green, Folong & $\begin{array}{l}\text { young shoot and } \\
\text { leaves; vegetable }\end{array}$ & 0.30 & 0.25 & - \\
\hline $\begin{array}{l}\text { Apium graveolens } \\
\text { SCA } 356\end{array}$ & Apiaceae & Celery & $\begin{array}{l}\text { leaves; } \\
\text { spice }\end{array}$ & 2.48 & 6.83 & $10 \pm 0.0$ \\
\hline $\begin{array}{l}\text { Gnetum africanum } \\
\text { SCA } 4120\end{array}$ & Gnetaceae & Eru, Okok & leaves; vegetable & 2.59 & 2.59 & $7.0 \pm 0.0$ \\
\hline $\begin{array}{l}\text { Irvingia gabonensis } \\
\text { SCA } 4645\end{array}$ & Irvingiaceae & $\begin{array}{l}\text { Bush mango, } \\
\text { Ogbonoh }\end{array}$ & $\begin{array}{l}\text { seed; } \\
\text { vegetable }\end{array}$ & 3.49 & 5.82 & $11.0 \pm 0.0$ \\
\hline $\begin{array}{l}\text { Manihot esculenta } \\
\text { SCA } 3800\end{array}$ & Euphorbiaceae & Cassava & $\begin{array}{l}\text { young shoot and } \\
\text { leaves; vegetable }\end{array}$ & 1.30 & 1.30 & $8.0 \pm 0.0$ \\
\hline $\begin{array}{l}\text { Petroselinum crispum } \\
25583 / \mathrm{HNC}\end{array}$ & Apiaceae & Parsley & leaves; spice & 7.50 & 8.82 & $9.0 \pm 0.0$ \\
\hline $\begin{array}{l}\text { Solanum nigrum } \\
\text { SCA } 4248\end{array}$ & Solanaceae & $\begin{array}{l}\text { Huckleberry, } \\
\text { Njamanjama }\end{array}$ & $\begin{array}{l}\text { young shoot and } \\
\text { leaves; vegetable }\end{array}$ & 1.85 & 3.36 & $8.0 \pm 0.0$ \\
\hline $\begin{array}{l}\text { Telfairia occidentalis } \\
\text { SCA } 2856\end{array}$ & Cucumbitaceae & Oko-obong & $\begin{array}{l}\text { young shoot and } \\
\text { leaves; vegetable }\end{array}$ & 2.78 & 5.01 & $9.0 \pm 0.0$ \\
\hline Gentamicin (PC) & & & & & & $22 \pm 0.0$ \\
\hline
\end{tabular}

PC - positive control.

*Zone of inhibition against $S$. aureus.

days and a crude extract was prepared by filtration and rotary evaporation with the water bath temperature set at $65^{\circ} \mathrm{C}$. The extracts were kept in open containers at room temperature to dry to a constant mass, which was then stored at $4^{\circ} \mathrm{C}$ and tested within one week (Mbah et al., 2012).

\section{Determination of the antifungal activity of extracts}

Three fungal species (Fusarium oxysporum, Fusarium solani, Colletotrichum sp.) previously shown to cause tomato fruit spoilage postharvest were obtained from the Biotechnology Unit of the University of Buea. They had been isolated from tomatoes and characterised using molecular tools in another study (Takam et al., 2019). They were cultured and tested by disc diffusion on a Muller Hinton (MH) agar plate (containing Chloramphenicol $0.05 \mathrm{mg} / \mathrm{mL}$ ) as described (Takam et al., 2019). Discs (containing 1 to $100 \mathrm{mg}$ ) were tested with positive (Econazole $1 \mathrm{mg} / \mathrm{mL}$ ) and negative controls (Tween-80). The plates were incubated at room temperature for 4 days and zones of inhibition measured.

The minimum inhibitory concentration (MIC) was determined for extracts of Irvingia gabonensis and Apium graveolens), which were active in the disc diffusion test according to the European Committee for Antimicrobial Susceptibility Testing (EUCAST, 2008), as described previously (Takam et al., 2019). The final extract concentration in $100 \mu \mathrm{L}$ MH broth 
in a 96-well microtitre plate was 1 to $100 \mathrm{mg} / \mathrm{mL}$ in duplicate with positive (Fluconazole $200 \mu \mathrm{g} / \mathrm{mL}$ ) and negative controls (no extract). Then, $100 \mu \mathrm{L}$ of a McFarland 0.5 conidial spore suspension of a 5-day culture was added, the plate incubated at room temperature and the absorbance read at $595 \mathrm{~nm}$ (EmaxMolecular Devices Corporation, California, USA) at $0,24,48$ and $72 \mathrm{~h}$. The lowest MIC value after visual observation and confirmed using absorbances was recorded.

\section{Determination of the antibacterial activity of extracts}

Staphylococcus aureus (Gram-positive) and Escherichia coli (Gram-negative) were obtained from the stock of the Biotechnology Unit, University of Buea (originally isolated from clinical specimens and characterized in the medical laboratory of the Buea Regional referral hospital). They were further characterized using cultural and biochemical tests (API $20 \mathrm{E}$ test kit, Biomérieux, France). The disc diffusion method was used according to the Clinical and Laboratory Standards Institute procedure (CLSI, 2012), as described (Bate et al., 2018), with $4 \mathrm{mg}$ discs on Muller Hinton $(\mathrm{MH})$ agar and zones of inhibition recorded.

The MIC was determined (for S. aureus inhibited in the disc test) by the micro-dilution method (Mbah et al., 2012) with some modifications. The extract (100 $\mu \mathrm{L}$ of 0.5 to $16 \mathrm{mg} / \mathrm{mL}$ final concentration) was incubated with bacteria $\left(100 \mu \mathrm{L}\right.$ of $\left.6 \times 10^{5} \mathrm{CFU} / \mathrm{mL}\right)$ in a $\mathrm{MH}$ broth in duplicate wells in a 96-well microtitre plate at $37^{\circ} \mathrm{C}$ for $24 \mathrm{~h}$. Negative (no extract) and positive control $(20 \mu \mathrm{g} / \mathrm{mL}$ Gentamicin) wells were included. The MIC was the lowest concentration that showed no turbidity and was determined as for the antifungal assay above.

Determination of nutritive value. Nutrition value was determined only for Irvingia gabonensis seeds and Apium graveolens leaves which demonstrated antimicrobial activity using the standard analytical methods of the Association of Official Analytical Chemists (AOAC, 2000). All analyses were done in duplicate and are briefly described below. Fresh vegetable leaves were processed and stored in airtight containers at room temperature until they were analyzed.
Moisture content was determined in the fresh sample $(2 \mathrm{~g})$ in crucibles heated in an oven (Heraeus $\mathrm{T}$ 6060 , Germany) as required and the percentage moisture content calculated (AOAC, 2000). The lipid content was estimated by soxhlet extraction from $4 \mathrm{~g}$ of a sample with $200 \mathrm{~mL}$ of hexane at $70-80^{\circ} \mathrm{C}$ for $16 \mathrm{~h}$. The extract was concentrated by rotary evaporation, dried to completely remove the residual solvent and weighed.

For the crude fiber content, a defatted sample ( $2 \mathrm{~g})$ was boiled with $1.25 \%$ of $\mathrm{H}_{2} \mathrm{SO}_{4}$ and bumping chips for $30 \mathrm{~min}$, the mixture filtered (Whatman no. 1) and then washed with boiled distilled water to completely remove acid. The residue was re-boiled with $1.25 \%$ $\mathrm{NaOH}$, filtered and washed serially with $1.25 \% \mathrm{H}_{2} \mathrm{SO}_{4}$, hot distilled water and $70 \%$ ethanol. The residue was dried in a crucible $\left(80^{\circ} \mathrm{C}\right.$ for $\left.3 \mathrm{~h}\right)$, incinerated $\left(500^{\circ} \mathrm{C}\right)$, and the fiber content determined from the recorded weights.

The protein content was estimated by the Kjeldahl method (AOAC, 2000) following three steps: mineralization, distillation and titration of the sample to obtain the nitrogen content, which was multiplied by a conversion factor of 6.25 to obtain the crude protein content.

The ash content was determined in $2 \mathrm{~g}$ of the milled sample in a crucible and incinerated for $4 \mathrm{~h}$ at $600^{\circ} \mathrm{C}$ in a furnace (Kendro 1252F, Germany). The carbohydrate content was determined by subtraction after the content of all the other nutrients had been determined.

Ten minerals were assayed. One gram of the sample was weighed and dry-ashed in a muffle furnace at $450^{\circ} \mathrm{C}$, then allowed to cool in a desiccator and diluted using a mixture $(400 \mathrm{~mL}$ conc. $\mathrm{HCl}$ and $133 \mathrm{~mL}$ of $70 \% \mathrm{HNO}_{3}$ ). The solution was used to measure minerals using an atomic absorption spectrophotometer at corresponding wavelengths.

\section{Vitamin C was determined by iodometric titration} as described by Dioha et al. (2011). Briefly, $5 \mathrm{~g}$ of the sample was macerated (in $50 \mathrm{~mL}$ distilled water for $2 \mathrm{~h}$ ) and the extract centrifuged (Eppendorf 5810R, Germany). Then $1 \mathrm{~mL}$ of supernatant was diluted, acidified ( $1 \mathrm{~mL}$ of $2 \mathrm{~N} \mathrm{H}_{2} \mathrm{SO}_{4}$ ), after which $1 \mathrm{~mL}$ of $1 \%$ starch solution was added and rapidly titrated against sodium thiosulphate. Vitamin C content was calculated against a titrated distilled water blank. 


\section{Data analysis}

All laboratory analyses were done in duplicate. Zone diameters recorded from the disc diffusion tests for antifungal activity were plotted against the amount of extract using Microsoft Excel 2010. Data for nutritive values were reported as means \pm standard deviation (S.D.).

\section{RESULTS AND DISCUSSION}

Antifungal and antibacterial activities of extracts In the disc diffusion test, three of the nine vegetable extracts showed high antifungal activity with zones of inhibition from 10 to $21 \mathrm{~mm}$. I. gabonensis extract showed dose-dependent activity against both Fusarium species. I. gabonensis was the most active extract with the highest inhibition zones against $F$. oxysporum $(21 \mathrm{~mm})$ and $F$. solani $(20 \mathrm{~mm})$ at $100 \mathrm{mg} / \mathrm{disc}$ (Fig. 1). Apium graveolens and Allium porrum showed activity against $F$. solani at $4 \mathrm{mg}$ and $20 \mathrm{mg}$ extract per disc giving zones of $15 \mathrm{~mm}$ and $12 \mathrm{~mm}$ respectively. No extract was active against Colletotrichum sp. Meanwhile, eight extracts produced smaller zones of inhibition of 8-12 mm against $S$. aureus with no zone against $E$. coli. The highest activity $(12 \mathrm{~mm})$ was

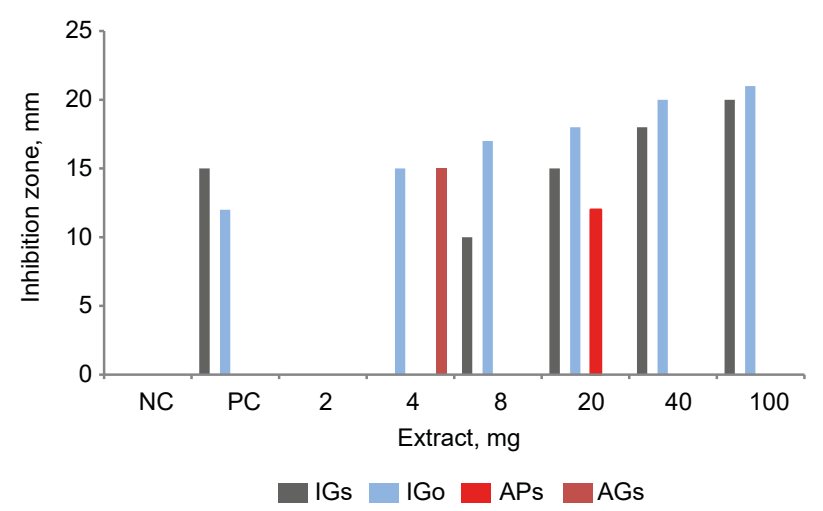

Fig. 1. Antifungal activities of methanol extracts of Irvingia gabonensis, Apium graveolens and Allium porrum. IGs and IGo: I. gabonensis activities against Fusarium sola$n i$ and Fusarium oxysporum respectively. APs and AGs: $A$. porrum and $A$. graveolens activities against $F$. solani respectively. $\mathrm{NC}-$ negative control, Tween- $80,1 \mathrm{mg} / \mathrm{mL}$. $\mathrm{PC}$ - positive control, Econazole, $1 \mathrm{mg} / \mathrm{mL}$, against $F$. solani (PCs) and F. oxysporum (PCo) respectively shown by Allium porrum. Only Amaranthus cruentus was not active. The small zones of inhibition recorded only against $S$. aureus suggests weak antibacterial activity.

In the micro-dilution assays, I. gabonensis showed the lower MIC value $(6.25 \mathrm{mg} / \mathrm{mL})$ against $F$. oxysporum, while A. graveolens had a MIC of $50 \mathrm{mg} / \mathrm{mL}$ against the same fungus. However, MIC values were recorded against bacteria for only two extracts, $I$. $g a$ bonensis $(2 \mathrm{mg} / \mathrm{mL})$ and A. porrum $(8 \mathrm{mg} / \mathrm{mL})$. Though small zones of inhibition were only recorded against $S$. aureus, I. gabonensis had a lower MIC value $(2 \mathrm{mg} / \mathrm{mL})$ than in the antifungal assay $(6.25 \mathrm{mg} / \mathrm{mL})$. The quantitative MIC results are more reliable and show that I. gabonensis possesses antibacterial activity.

High antifungal activity was recorded against F. oxysporum and F. solani, which cause tomato spoilage. These results suggest a possible use of this extract to prevent postharvest damage of tomatoes by these fungi, which were shown in another study to attack most frequently the fruit around Buea in Cameroon (Takam et al., 2019). Preservation of tomato quality will prevent loss of its nutrients and prevent possible harm to human health when consumed.

The antifungal and antibacterial activities recorded for I. gabonensis reflect the high antimicrobial potential of the seed, which may be protective against some microbial infections when consumed in the diet. The activities of Apium graveolens and Allium porrum also indicate potential antimicrobial health benefits. Few studies have been carried out on the antimicrobial properties of I. gabonensis seeds. Interestingly, a study done in Nigeria also reported higher antifungal than antibacterial activity for I. gabonensis seeds (Dosumu et al., 2012). A study conducted in Cameroon on the leaves of I. gabonensis documented their weak antibacterial activity (Nayim et al., 2018). Edziri et al. (2012) reported higher antifungal activity (MIC $=0.08$ to $0.31 \mathrm{mg} / \mathrm{mL}$ ) for A. graveolens against three clinical Candida species. On the contrary, Shad et al. (2011) observed no activity for the methanol extract of Apium graveolens against $F$. solani in Pakistan. This could be due to differences in the varieties found in Pakistan and Cameroon.

A second important finding was that bioactive vegetables were found to be good sources of some 
nutrients: I. gabonensis was rich in lipids, iron, phosphorus and potassium, while Apium graveolens was rich in protein, calcium, phosphorus, potassium, zinc and vitamin $\mathrm{C}$ (Table 2 and Table 3). The nutritional importance of I. gabonensis and A. graveolens was established, since they showed the highest antifungal

Table 2. Proximate composition of Irvingia gabonensis and Apium graveolens

\begin{tabular}{lcc}
\hline \multicolumn{1}{c}{ Property } & $\begin{array}{c}\text { Irvingia gabonensis } \\
\%\end{array}$ & $\begin{array}{c}\text { Apium graveolens } \\
\%\end{array}$ \\
\hline Moisture & $3.23 \pm 0.08$ & $15.23 \pm 2.22$ \\
Ash & $2.48 \pm 0.01$ & $13.03 \pm 1.68$ \\
Lipid & $69.90 \pm 0.14$ & $17.90 \pm 0.14$ \\
Fiber & $8.25 \pm 0.21$ & $10.96 \pm 0.64$ \\
Protein & $10.12 \pm 0.39$ & $35.35 \pm 0.49$ \\
Carbohydrates & $6.01 \pm 1.51$ & $7.40 \pm 0.12$ \\
\hline
\end{tabular}

Table 3. Macro minerals, micro minerals and vitamin $\mathrm{C}$ content of Irvingia gabonensis and Apium graveolens

\begin{tabular}{|c|c|c|}
\hline Minerals & $\begin{array}{c}\text { Irvingia gabonensis } \\
\text { seeds } \\
\mathrm{mg} / 100 \mathrm{~g}\end{array}$ & $\begin{array}{c}\text { Apium graveolens } \\
\text { leaves } \\
\mathrm{mg} / 100 \mathrm{~g}\end{array}$ \\
\hline \multicolumn{3}{|c|}{ Macro minerals } \\
\hline Sodium & $7.39 \pm 0.09$ & $0.19 \pm 0.00$ \\
\hline Potassium & $180.94 \pm 2.64$ & $276.51 \pm 1.41$ \\
\hline Calcium & $18.55 \pm 0.59$ & $51.05 \pm 1.42$ \\
\hline Phosphorous & $359.67 \pm 1.89$ & $622.14 \pm 2.69$ \\
\hline Magnesium & $13.25 \pm 0.33$ & $0.47 \pm 0.057$ \\
\hline \multicolumn{3}{|c|}{ Micro minerals } \\
\hline Manganese & $8.06 \pm 0.08$ & $0.02 \pm 0.014$ \\
\hline Zinc & $5.42 \pm 0.12$ & $16.86 \pm 0.27$ \\
\hline Iron & $276.51 \pm 1.41$ & $1.04 \pm 0.06$ \\
\hline Copper & $2.9 \pm 0.88$ & $0.13 \pm 0.028$ \\
\hline Iodine & $0.48 \pm 0.014$ & $0.06 \pm 0.028$ \\
\hline Vitamin C & 0.49 & $58.04 \pm 0.75$ \\
\hline
\end{tabular}

activities. The proximate analysis showed the highest macro nutrient content in I. gabonensis to be for lipids (69.90\%) and protein (35.35\%) in A. graveolens. The rest of the components were present to varying degrees. The lipid content of I. gabonensis is greater than the value reported by Dosumu et al. (2012) and confirms reports by Fokou et al. (2004), which state that $I$. gabonensis seeds are richer in fat content than Cucumeropsis mannii (egusi; 42-57\%) and Glycine max (soya beans; 45\%). Both $A$. graveolens and $I$. gabonensis have a higher lipid content than Moringa oleifeira seeds $(13.35 \%)$, as stated in the report by Ijarotimi et al. (2013), and the protein content of $A$. graveolens is higher than the value (17.94\%) reported by Salem (2014) in Pakistan, thus showing these two plants to be good sources of lipids and proteins respectively. The moisture content (15\%) of $A$. graveolens is much lower than the $81.00 \%$ reported by Qureshi et al. (2014) for species from Pakistan; it shows that the Cameroonian varieties of $A$. graveolens can be easier to store. A. graveolens had lower ash content (13\%) than the $23.19 \%$ reported by Salem (2014), but a little more than Vernonia amygdalina (bitter leaf; $11.7 \%)$ and Moringa oleifera leaves (12.23 $\pm 0.03 \%$; Karuna and Rajni, 2014). A. graveolens leaves had lower (10.96\%) crude fiber than the $19.28 \%$ reported by Qureshi et al. (2014), but higher than I. gabonensis, which is not unexpected, since A. graveolens leaves were used. However, the fiber for I. gabonensis $(8.25 \%)$ was similar to that $(10.4 \%)$ reported by Onojah et al. (2018). Since I. gabonensis has a much higher lipid content (69.90\%) than A. graveolens (17.90\%), it is proved to be a better energy source when consumed.

The macro minerals revealed that both vegetables are richer in phosphorous and potassium than the other minerals (Table 3). However, phosphorous and potassium were lower than reported for Moringa olefeira leaves (Asante et al., 2014). Nevertheless, consumption of about $224 \mathrm{~g}$ and $129 \mathrm{~g}$ of I. gabonensis seeds and $A$. graveolens leaves respectively can meet the RDA for the two minerals. The two vegetables are not very good sources of sodium. However, this is not of great consequence, since it is commonly obtained from table salt or common salt.

Of the micro minerals analysed in the two vegetables, iron was highest in I. gabonensis, while zinc was highest in A. graveolens. Iron deficiency anaemia 
is still a public health problem, so good food sources of iron cannot be overemphasized. The iron content $(276.51 \mathrm{mg} / 100 \mathrm{~g})$ of I. gabonensis seed in this study is higher than the $101.01 \mathrm{mg} / \mathrm{kg}$ reported by Dosumu et al. (2012) and the $11.85 \mathrm{mg} / 100 \mathrm{~g}$ for Moringa olefeira seeds reported by Anjorin et al. (2010). A. graveolens leaves had higher zinc content than I. gabonensis but was less than the $305.2 \mu \mathrm{g} / \mathrm{g}$ reported for wild celery by Qureshi et al. (2014). Recommended dietary allowance - RDA for iron is $8 \mathrm{mg} / \mathrm{day}$ for adults males, $18 \mathrm{mg}$ /day for adult females of child bearing age and a little more for pregnant and lactating women. Both vegetables can more than meet the RDA for iron and thus can be good sources of iron when consumed. Zinc is now in focus as an essential mineral for sexual reproduction, cell repair and wound healing. It is a component of many enzymes. In this study, its content in both plants can provide more than $50 \%$ of RDA $(10 \mathrm{mg})$. The two vegetables can also meet the RDA for manganese but $I$. gabonensis seeds are better sources of manganese. Copper and iodine were both higher in I. gabonensis than in A. graveolens. RDAs for copper and iodine for adults are about $1 \mathrm{mg} /$ day and $150 \mu \mathrm{g} /$ day respectively and these two minerals can meet more than the RDA for $100 \mathrm{~g}$ consumption per day. This is important considering the role of copper in metabolism and cretinism in permanent damage caused by iodine deficiency in infants and children. The two vegetables have appreciable levels of phosphorous and iron, so they can be incorporated in complementary food, because of their importance in the bones and blood, as well as energy metabolism.

Vitamin C is used in the human body for collagen synthesis in teeth, bone and connective tissues of blood vessels, where it plays the role of an enzyme cofactor. Vitamin C is also an antioxidant. A deficiency in it can lead to scurvy, which is the breakdown of skin, blood vessels and teeth. The vitamin $\mathrm{C}$ content of $I$. gabonensis seeds was much lower than the value $76.04 \mathrm{mg} / 100 \mathrm{~g}$ reported by Olayiwola et al. (2013). In this study, A. graveolens leaves contain more vitamin C than I. gabonensis seeds, but with a lower content than the level of $60.35 \mathrm{mg} / 100 \mathrm{~g}$ that was reported by Qureshi et al. (2014). The RDA for vitamin $\mathrm{C}$ for adults is $60-70 \mathrm{mg} / \mathrm{day}$ and $45 \mathrm{mg}$ for children. This can be met by consuming about 103-120 $\mathrm{g}$ and $77.5 \mathrm{~g}$ of A. graveolens leaves respectively. Moreover, consuming $110-128 \mathrm{~g}$ and $82.72 \mathrm{~g}$ of I. gabonensis seeds will meet the RDA in adults and children respectively. The absorption of nutrients, minerals and vitamin $\mathrm{C}$ may not be affected, because antinutrients like oxalate and phytate which can reduce their absorption have not been reported in vegetables and spices.

\section{CONCLUSION}

This study has shown that the vegetables selected possess antimicrobial activity with considerable antifungal activity in I. gabonensis and Apium graveolens. The antifungal activity of I. gabonensis, A. graveolens, and Allium porrum indicates a potential preservative effect in the tomato postharvest. I. gabonensis seeds and $A$. graveolens both have high lipid, protein, vita$\min \mathrm{C}$, zinc, copper and phosphorous content. Manganese and iron were also high in I. gabonensis seeds. Therefore consumption of even moderate quantities of I. gabonensis seeds and A. graveolens leaves can meet the RDA for several nutrients for both adults and children and also provide protective antimicrobial action.

\section{ACKNOWLEDGMENTS}

The University of Buea supported this work through facilities provided in the Department of Biochemistry and Molecular Biology, the Life Science laboratory and the Biotechnology Unit all of the Faculty of Science, University of Buea, Cameroon.

\section{REFERENCES}

Abia, W. A., Numfor, F. A., Wanji, S., Tcheuntue, F. (2007). Energy and nutrient contents of "waterfufu and eru". Afr. J. Food Sci., 1(2), 016-019. https://academicjournals.org/journal/AJFS/article-abstract/EAC5F1711127

Achidi, A. U., Ajayi, O. A., Maziya-Dixon, B., Bokanga, M. (2008). The effect of processing on the nutrient content of cassava (Manihot esculenta Crantz) leaves. J. Food Process. Pres., 32(3), 486-502. https://doi.org/10.1111/ j.1745-4549.2007.00165.x

Anjorin, T. S., Ikokoh, P., Okolo, S. (2010). Mineral composition of Moringa oleifera leaves, pods and seeds from two regions in Abuja, Nigeria. Int. J. Agric. Biol., 12(3), 431-434.

Asseng, C. C., Tiako, T. E. A., Okolle, J., Ambang, Z., Monkam, T. F. (2017). Effect of culture density of black 
Wandji, F. N. B., Achidi, A. U., Ngemenya, M. N., Nyongbela, K. D., Tiencheu, B. (2019). In vitro antifungal, antibacterial activities and nutritional value of nine Cameroonian edible vegetables and spices. Acta Sci. Pol. Technol. Aliment., 18(3), 333-341. http:// dx.doi.org/10.17306/J.AFS.2019.0664

nightshade (Solanum nigrum) on the insect infestation. Plant., 5(5-1), 19-26.

AOAC (2000). Official methods of analysis of AOAC (17 ed., vol. 1). Maryland: Association of Official Analytical Chemists.

Asante, W. J., Nasare, I. L., Dery, D. T., Kwame, O. B., Kwami, B. K. (2014). Nutrient composition of Moringa oleifera leaves from two agro-ecological zones in Ghana Afr. J. Plant. Sci., 8(1), 65-71. https://doi.org/10.5897/ AJPS2012.0727

Bate, P. N. N., Orock, A. E., Nyongbela, K. D., Babiaka, S. B., Kukwah, A., Ngemenya, M. N. (2018). In vitro activity against multi-drug resistant bacteria and cytotoxicity of lichens collected from Mount Cameroon. J. King Saud Univ. Sci. https://doi.org/10.1016/j.jksus.2018.09.001

Clinical and Laboratory Standards Institute. Performance standards for antimicrobial susceptibility testing; twenty second informational supplement M100 - S22. Wayne. (2012). Retrieved December 15, 2016, from: http://antimicrobianos.com.ar/ATB/wp-content/uploads/2012/11/ M100S22E.pdf.

Dioha, I. J., Olugbemi, O., Onuegbu, T. U., Shahru, Z. (2011). Determination of ascorbic acid content of some tropical fruits by iodometric titration. Int. J. Biol. Chem. Sci., 5(5), 2180-2184. http://dx.doi.org/10.4314/ijbcs. v5i5.37

Dosumu, O. O., Oluwaniyi, O. O., Awolola, G. V., Oyedeji, O. O. (2012). Nutritional composition and antimicrobial properties of three Nigerian condiments. Niger. Food J., 30(1), 43-52. http://dx.doi.org/10.1016/S01897241(15)30012-6

Edziri, H., Ammar, S., Souad, L., Mahjoub, M. A., Mastouri, M., Aouni, M., ..., Verschaeve, L. (2012). In vitro evaluation of antimicrobial and antioxidant activities of some Tunisian vegetables. South Afr. J. Bot., 78, 252-256. https://doi.org/10.1016/j.sajb.2011.09.012

EUCAST Definitive Document E. Def 9.1 (2008). Method for the determination of broth dilution minimum inhibitory concentrations of antifungal agents for conidia forming moulds. Retrieved June 30, 2019, from: http:// www.eucast.org/astoffungi/METHODSINANTIFUNGALSUSCEPTIBILITYTESTING/susceptibility testing_of_moulds/

Fokou, E., Achu, M. B., Tchounguep, F. M. (2004). Preliminary nutritional evaluation of 5 species of egusi seeds in Cameroon. Afr. J. Food Agric. Nutr. Dev., 4(1), 23-25.

Fontem, D. A., Gumedzoe, M. Y. D., Nono-Womdim, R. (1999). Biological constraints in tomato production in the Western Highlands of Cameroon. Tropicultura, 1617(2), 89-92.
Ijarotimi, O. S., Adeoti, O. A., Ariyo, O. (2013). Comparative study on nutrient composition, phytochemical, and functional characteristics of raw, germinated, and fermented Moringa oleifera seed flour. Food Sci. Nutr., 1(6), 452-463. https://doi.org/10.1002/fsn3.70

Karuna, S. V., Rajni, N. (2014). Nutritional assessment of different parts of Moringa oleifera collected from Central India. J. Nat. Prod. Plant. Res., 4(1), 81-86.

Mbah, J. A., Ngemenya, M. N., Abawah, A. L., Babiaka, S. B., Nubed, L. N., Nyongbela, K. D., ..., Efange, S. M. N. (2012). Bioassay-guided discovery of antibacterial agents: in vitro screening of Peperomia vulcanica, Peperomia fernandopoioana and Scleria striatinux. Ann. Clin. Microbiol. Antimicrob., 11, 10. https://doi. org/10.1186/1476-0711-11-10

Nayim, P., Mbaveng, A. T., Wamba, B. E. N., Fankam, A. G., Dzotam, J. K., Kuete, V. (2018). Antibacterial and antibiotic-potentiating activities of thirteen Cameroonian edible plants against gram-negative resistant phenotypes. Sci. World J. ID 4020294. https://doi. org/10.1155/2018/4020294

Ngome, I., Foeken, D. (2012). "My garden is a great help": gender and urban gardening in Buea, Cameroon. Geo -Journal, 77(1), 103-118. https://doi.org/10.1007/s107 08-010-9389-z

Noumedem, J. A. K., Mihasan, M., Lacmata, S. T., Stefan, M., Kuiate, J. R., Kuete, V. (2013). Antibacterial activities of the methanol extracts of ten Cameroonian vegetables against Gram-negative multidrug-resistant bacteria. BMC Compl. Altern. Med., 13, 26. https://doi. org/10.1186/1472-6882-13-26

Oguntibeju, O. O., Truter, E. J., Esterhuyse. A. J. (2013). The role of fruit and vegetable consumption in human health and disease prevention. London: IntechOpen. http://dx.doi.org/10.5772/50109

Olayiwola, I. O., Akinfenwa, V. O., Oguntona, C. O., Sanni, S. A., Onabanjo, O. O., Afolabi, W. A. O. (2013). Phytonutrient, antioxidant and mineral composition of some wild fruits in South West Nigeria. Niger. Food J., 31(2), 33-40. http://dx.doi.org/10.1016/S0189-7241 (15)30074-6

Onojah, P. K., Musa, F., Ugwuowo, E. N. (2018). Comparative studies on the proximate composition and anti-nutrient content of the cotyledons of two species of Irvingia (Ogbono) sold in Anyigba Main Market, Kogi State, Nigeria. J. Chem. Soc. Niger., 43(2), 98-107.

Qureshi, K., Tabassum, F., Neelam, Amin, M., Akram, M. Z., Zafar, M. (2014). Investigation of mineral constituents of Apium graveolens L. available in Khyber Pakhtunkhwa Pakistan. J. Pharm. Phytochem., 3(4), 234-239. 
Wandji, F. N. B., Achidi, A. U., Ngemenya, M. N., Nyongbela, K. D., Tiencheu, B. (2019). In vitro antifungal, antibacterial activities and nutritional value of nine Cameroonian edible vegetables and spices. Acta Sci. Pol. Technol. Aliment., 18(3), 333-341. http:// dx.doi.org/10.17306/J.AFS.2019.0664

Roser, M., Ritchie, H. (2016). Burden of disease. Retrieved March 25, 2019, from: https://ourworldindata.org/burden-of-disease

Salem, A. A. (2014). Biochemical and nutritional impact of celery and turnip leaves on induced obese by high fat diet (HFD). J. Food Nutr. Sci., 2(6), 285-302. https:// dx.doi.org/10.11648/j.jfns.20140206.17

Shad, A. A., Hamid, U. S., Bakht, J., Iqbal, M. C., Ullah, J. (2011). Nutraceutical potential and bioassay of Apium graveolens L. grown in Khyber Pakhtunkhwa - Pakistan. J. Med. Plants. Res., 5(20), 5160-5166.

Slavin, J. L., Lloyd, B. (2012). Health benefits of fruits and vegetables. Adv. Nutr., 3(4), 506-516. http://dx.doi. org/10.3945/an.112.002154
Takam, G. H. F., Tatsinkou, F. B., Mbah, J. A., Bate, P. N. N., Ngemenya, M. N. (2019). Morphological and PCR characterization of fungi isolated from tomato postharvest, and potential control of fruit spoilage by antifungal plant extracts. Int. Food. Res. J., 26(1), 123-131.

Veeresham, C. (2012). Natural products derived from plants as a source of drugs. J. Adv. Pharm. Technol. Res., 3(4), 200-201. http://dx.doi.org/10.4103/2231-4040.104709

Wagacha, J. M., Muthomi, J. W. (2008). Mycotoxin problem in Africa: Current status, implications to food safety and health and possible management strategies. Int. J. Food Microbiol., 124(1),1-12.https://doi.org/10.1016/j.ijfood micro.2008.01.008 